$\frac{\mathrm{DE}}{\mathrm{G}} \stackrel{\substack{\text { DE GRUYTER } \\ \mathrm{OPEN}}}{\text { ECONOMIC THEMES (2014) 52 (1): 51-64 }}$

\title{
ENCOURAGING INNOVATIVENESS OF SMALL AND MEDIUM ENTERPRISES IN SERBIA TO SUPPORT COMPETITIVENESS IMPROVEMENT IN THE POST-CRISIS PERIOD
}

\author{
Maja Ivanović-Đukić \\ University of Niš, Faculty of Economics, Serbia \\ \maja.djukic@eknfak.ni.ac.rs \\ Maja Lazić \\ $\triangle$ lazic.maya@gmail.com
}

UDC

330.341.1:

334.012.63/.64

Review paper

Received:

18.10.2013

Accepted:

20.02.2014

\begin{abstract}
The global economic crisis has taken a number of consequences. In order to overcome them, many of various measures on macroeconomic and microeconomic level should be implemented in the post-crisis period. A large number of developed and developing countries as a key lever in the post-crisis period would recognize the SME sector, so that the greatest number of macroeconomic policies aims at fostering its competitiveness. Previously, a competitive advantage of SMEs was generally founded on focusing on specific markets, competing in fragmented industry or on cost leadership. Nowdays, the ability to innovate is the most important source of their competitiveness. However, since the capacities of SMEs to introduce technological innovations are generally limited, strong macroeconomic support for increasing innovativeness of SMEs is necessary. This paper will explain measures which may increase innovativeness of SMEs and the impact of SMEs innovations on their competitiveness and the competitiveness of the economy in which they operate. A special emphasis will be on the analysis of innovativeness of the SMEs in Serbia.
\end{abstract}

Keywords: innovation, competitiveness, small and medium-sized enterprises, global economic crisis.

\section{Introduction}

The current economic crisis is the result of the mortgage crisis in the U.S.A., but it was soon transferred from the financial to the real sector. Purchasing power of the citizens dropped and this lead to the sale and production decrease in many companies. Reducing the volume of business 
dealings in companies resulted in the dismissal of vast number of workers, which decreased the demand even more. This is how the enchanted circle of problems was created and this lead to the economic collapse in many countries during 2008 and 2009. The crisis occurred in the countries whose level of involvement in international business operations was the greatest (the most developed countries in the world), but it did not bypass less developed countries, such as Serbia.

Under the influence of the Global Economic Crisis, there was the withdrawal of foreign capital and there was investment decrease in Serbia. All this resulted in the inflationary pressures (currency liquidity decrease and national currency depreciation), and caused the aggravation of the credit conditions (increase in interest rates, the shortening of the payment periods etc.), and caused many problems to the companies such as: difficulties in managing cash flows, reducing earning capacities, production decrease, slowdown of the business cycles etc. Because of these problems, the economic growth in Serbia was slowed down, and the competitive strength of Serbia dropped at the international level (The World Economic Forum 2012's Report). ${ }^{1}$

In the post-crisis period, Serbia's economic policy was oriented to the increase of export and investments, as the basic drivers of economic development. Export increase implies encouraging innovativeness and productivity of the business entities in Serbia. Whereas small and medium-sized enterprises comprise $99.8 \%$ of the total number of companies, they generate $66.4 \%$ of the employees and $65.3 \%$ of sales circulation, the focus in the paper, will be only on them (Ministry of Economy and Regional Development's Report, 2011, 13). It will be explained how, by encouraging innovativeness of small- and medium-sized enterprises, their competitive advantage at local and global market could be increased. The aim of this paper is to show to the managers of SME, how significant the innovations are, in order to increase competitiveness. Also, the aim of this paper is to make a suggestion to the creators of macroeconomic policy in Serbia how necessary the implementation of structural reforms in terms of encouraging innovativeness of small- and medium-sized enterprises is.

The starting hypothesis of this paper is that by successfully managing innovativeness, the competitiveness of small and medium-sized enterprises in Serbia could be increased, and this could contribute to the overcoming of the consequences of the world economic crisis. In terms of the research methodology, the authors of this paper, based on theoretical sources and

\footnotetext{
${ }^{1}$ According to the Global Competitiveness Index, the World Economic Forum in 2009, Serbia rated at 93th place. In 2010. Serbia rated at 96th place and period from 2011. to 2012 was at 95th place out of a total 144 countries for which the Global Competitiveness Index was calculated, behind most countries in the region (Slovenia, Montenegro, Croatia, Macedonia, Bulgaria, Romania, Albania, etc..).
} 
experience of the best worlds best practice, try to perceive this subject and aim of this paper, and the prove the starting hypothesis of this research.

\section{Importance of Innovativeness for SMEs' Competitiveness in the Post-Crisis Period}

The global economic crisis has changed the SMEs business environment in all countries, especially developing countries. Reduced liquidity, limited opportunities to obtain additional funding and collection of receivables have deteriorated of the financial situation of SMEs. On the other hand, more intensive market globalization contributes to strengthening the competitive pressure (Borch, Madsen, 2007, 109-125). Accordingly, SMEs need to build a strong competitive advantage based on lower production costs and differentiated products which would be more valued by consumers in comparing with competitive products (Lazić, 2013. str.72).

Previously, a competitive advantage of SMEs had generally been built by focusing on specific markets, compete in fragmented industry or by cost leadership (Thompson, Strickland, 2001, 193). However, in modern business conditions (which are characterized by variability of the market environment, globalization, market deregulation and high competition intensity, the factors that determine the competitiveness of the companies get a different importance), the more important source of the competitiveness is the innovation capability (European Innovation Management Landscape, 2012). Innovating implies a complex set of activities, from the creation of new ideas to its implementation into practice (Borch, Madsen, 2007, 109-125). This includes finding new resources/technologies and their usage (McAdam et al, 2010, 195), process of social change as the results of the new technology (Romero, Martine-Roman, $2012,178)$ and accept changes that are new to the company, group or society (Molina-Morales et al, 2011, 1). In other words, innovation is understood as innovate or modify something existing.

One of the key potentials for acquiring and sustaining competitive advantage of SMEs in the post-crisis period is implementation of new and original ideas which create new technologies, products, services and changes in creating added value for consumers (Kaufmann et al, 2012, 333-360). However, the importance of innovation for the competitiveness of SMEs depends on the type of innovation. Innovations include: technological innovations, social innovation and their combination (Martín-de Castro et al, 2013, 351-363). Technological innovations include creation of new products or new services based on new technological features or introduction a new type of technological processes in the enterprise. Social innovations include new ways in satisfying customers needs, changes in the company functioning, new government measures, new institutions in society, etc. (Galende ,De la Fuente, 2003, 715). 
The greatest importance for the competitiveness of companies have technological innovations that are results of research and development activites (Urbancová, 2013, 90.). The introduction of technological innovation for small and medium-sized enterprises enables: create completely new products, develop new usages of existing products, or improve existing products and develop new processes. First of all, usage of innovations enables the production of new and attractive high quality products and enables the company to differentiate from competitors and acquires competitive advantage. Also, by innovating existing products SMEs can increase their value for consumers and by process innovation SMEs can increase the efficiency of business operations and reduce production costs. Thanks to each of these aspects can be improved financial performances and competitiveness of small and medium-sized enterprises (Urbancová, 2013, 91).

At the same time, by improving products and services quality, creating and commercializing innovations and developing of new technologies, SMEs stimulate economic growth and contribute to the development of national competitiveness (Europeian Commission, 2012). The results of the empirical researches show that $50 \%-60 \%$ of the economic growth can be attributed to technological innovations (Milisavljević, 1993, 18). Also, the position of the companies at the international market is primarily determined by the level and intensity of the technological innovations, and only secondarily by the differences in prices, product quality and other business aspects.

Recognizing the key role of innovation for development of each country, Confederation of Indian Industry CII in cooperation with INSEAD (World Business School) and Canon India, developed the Global Innovation Index, a fundamental indicator of the performances of innovative activities in SMEs. Global index of innovation and competitiveness in the 2010-2011 Report data shows that countries with high innovation index, also have a higher index of competitiveness. (According to the Report, leaders in innovation are Sweden, Germany, Finland, the Netherlands and Denmark). Also, the use of statistical methods has proved positive correlation between the Global Innovation Index and the Global Competitiveness Index. Growth Global Competitiveness Index resulted in the Index of innovation growth, which confirms fact that improvement of competitiveness is consequence of the innovative activities growth (Bugar et al, 2012, 1849).

Encouraging innovativeness of SMEs can increase their competitiveness and competitiveness of the national economy in which they operate. But, the innovative capacity of small and medium-sized enterprises can be very limited, especially when they relate to technological innovation. Therefore, it is necessary to implement various measures at the national and local levels in order to increase the innovative capacity of SMEs. 


\section{Measures to Increase the Innovative Capacity of Small and Medium-Sized Enterprises}

Innovative capacity of the company's ability is to successfully implement innovations. According with the fact that innovative process includes the ability to find the idea (invention) and its introduction to the market (innovation), the innovative capacity of enterprises are conditioned by ability to find new ideas and possibilities for their realization. Implementation of each of these activities depends on specific characteristics of SMEs.

First of all, the specific characteristics of SMEs provide them implementions ideas that do not require large investments in research and development activities. Small enterprises are focused on an entrepreneur, who is by definition (Schumpeter, 1947, 152) characterized by a great degree of creativity. Entrepreneur's creativity provides new ideas that are the key source of SMEs innovations (Kaufmann, 2009, 212.). Also, SMEs can faster recognizing the specific consumers needs which can be a source of inovative ideas (Khazanchi et al, 2007, 187-218).

A great advantage of SMEs is a simple organizational structure, so that a manager is familiar with daily happenings and has a clear review of available resources. It enables him to efficiently organize the implementation of innovative solutions, do the relocation of resources and maximize the effect of synergy. The resources connection in different parts of organization and their use in different innovative projects increases the flexibility of small- and medium enterprises, and secures the risk dispersion. Apart from, successful implemention of innovative activities is conditioned by simple owner's structure, low level of formalization, the speed of making decisions and the possibility for connecting resources in different parts of an organization (Busse, Wallenburg, 2011, 183.). Thanks to these benefits SMEs can successfully introduce innovations as an answer to change customer needs, new models of organization, new marketing and management concepts. However, SMEs are faced with serious problems related to the introduction of technological innovation.

One of the problems SMEs are limited financial resources provided by the founder. Also, the acquiring of new resources through the accumulation of one's own capital can last very long, and funds from external sources are not always available. Limited financial resources reduce the possibility of financing the many innovative projects. Serious problems of SMEs are the result of lack of knowledge, technology needed to implement innovative projects and risk diversification inability. The risk of investment in the wrong innovation projects is extremely high, so that it often leads to collapse (Ivanović-Djukić, 2008, 317324.). 
Since the innovativeness of SMEs have a major impact on their competitiveness and in accordance with the fact that SMEs have a great share in the structure of the economy, in most countries are implemented various measures to encourage innovation of small and medium-sized enterprises.

In developed countries, the huge funds are allocated for the financing innovative projects of SMEs, organization various educational programs and there is a large number of consulting services and various forms of institutional support. For example, in 2013 the European Commission adopted Programme for the Competitiveness of enterprises and SMEs - COSME for the 2014-2020 period, which represents a continuation Competitiveness and Innovation Framework Programme - CIP. The main objectives of the program include creating an adequate business environment and providing necessary financial resources for develop innovative and competitive SMEs. The European Commission has adopted the Programme "Horizon 2020", whose objectives are complementary with COSME Programme goals. This program provided a budget of $\$ 3$ billion. The program is designed for funding high-risk research in order to encourage SMEs innovativeness and competitiveness. Funds under this program are intended for highly innovative SMEs with high potential for development, growth and internationalization, regardless of their business dealings. Financial resources are intended for financing all activities within the innovation cycle in SMEs. In addition to direct financial support, the program includes adequate training and mentoring provided by qualified professionals through the Enterprise Europe Network (European Commision, 2013).

The problems of small and medium-sized enterprises based on lack of knowledge and experience that can be overcome by: establishing scientific and technology parks, clustering, establishing business and technology incubators. Scientific and technological parks are organizations that primarily provide the necessary infrastructure for the innovation activities of the companies which implement new technologies ${ }^{2}$. Scientific parks are generally integrated with universities and technology centers, and they bridge the gap between research and development institutions and the business environment. Connected SMEs with these institutions can use resources and the results of scientific and technological research, transfer and implementation of new trehnology etc. This can significantly increase their innovative capacity (Stefanović, IvanovićDjukić, 2010, 187-208).

\footnotetext{
${ }^{2}$ Law on Innovation RS (Article 23) defines the scientific and technological park as a "commercial enterprise within a particular area provides infrastructure and professional services to higher education institutions, innovative organizations, and commercial enterprises and medium-high technology in a particular scientific, research and development or manufacturing grouping to connect them for significantly faster application of new technologies, the creation and entering the market of new products and services. "
} 
The experience of developed and developing countries shows that an important measure to encourage innovativeness of small and medium-sized enterprises can be clustering ${ }^{3}$. Clustering eliminates disadvantages of SMEs related to limited resources, lack of funding innovative projects and lack of knowledge and information. Clustering encourages SMEs innovativeness through: a) implementing investment projects, b) reduction cost of new products (thanks to the joint efforts of the cluster members) c) informing about technology projects and incentives that are implemented on the national and international level (adequate connections with the government and other public institutions) d) improving funds access and credit lines that will enable financing innovative projects. Clustering advantages in the area of innovations are reflected in faster recognizing customer needs, which influence on direction and concentration of innovations and faster response to customer needs. Necessary inputs, skills, resources and staff are available at particular location, which may contribute to its easier connection. Local investors and financial institutions grunted the necessary funds and offer lower interest rates on debt. All of these factors reduce the business risks, but it also provides entry barrier for firms outside the cluster. (Stefanović, Ivanović-Djukić, 2010, 187-208).

High-tech incubators very often named as technology incubators have great importance in the modern business environment characterized by intensive competition and needs for constant innovations. As a form of cooperation between universities and companies, high-tech incubators are one of the ways of establishing partnerships between the university and the local economy. In fact, researchers at universities and graduate students are the most important resources as holders of knowledge and new ideas that are generators of innovative products. Therefore, the cooperation of local SMEs and universities is an important precondition for economic development of certain regions. Some of the most important roles of universities in high-tech incubators are the following: stimulating research and innovative activities, identifying new product and business ideas at universities in order to obtain the status of tenants in the incubator, involving students on useful projects that are implemented in incubator (eg projects related to market research); supporting incubator tenants with various business related consultation and providing transfer of knowledge and know-how to them.

Additionally, finding strategic partners and offering different types of incentives to SMEs which cooperate with big business systems can increase the innovativeness of SMEs. In strategic alliances, associated company share resources, technology, knowledge and implement joint ventures in the areas of production, marketing, supply, distribution, etc. Small and medium size enterprises in strategic alliances can provide necessary financial resources or

\footnotetext{
3 "Clusters are geographic concentrations of interconnected companies and institutions in a specific business area” (Porter, 2008, 77-90)
} 
complementary assets such as adequate distribution channels and well-known brand name in order to be competitive in the globalized market segments. Transfer of technology represents a huge opportunity for future innovations and research activities of SMEs. By these and many other measures, SMEs limits related to innovative activites implementation could be removed, enabling increase of their competitiveness and competitiveness as economy as a whole.

\section{Innovativeness of SMEs in Serbia}

Similarly to other countries in the world, the participation of SMEs in economic activity in Serbia is very high. According to the report of the National Agency for Regional Development from 2011, in 2010, from total of 319,004 companies, the sector of small and medium-sized enterprises consists of 318,540 companies, i.e. $99.8 \%$. The sector of SMEs in Serbia takes $43.9 \%$ of all investments, it realizes $44.5 \%$ of export and $52.3 \%$ of all import (National Agency for Regional Development's Report, 2011, 63). Also, data for 2012 show that SME have strategic importance for economic development of a country and that they represent very important economic factors. Besides, SMEs in Serbia have overcome negative implications of the crisis more easily than big companies ${ }^{4}$. Thanks to the entrepreneurship and high level of flexibility, SMEs can adjust more quickly to new market condition than big corporations. For this reason SME have became the basis of the economic growth.

In order to maximize the capacities and use the potentials of SME in Serbia, in the post-crisis period, it is needed to continue with the efforts of economic policy directed toward the start up new ventures, subsidizing the business operations of the existing companies and improving the capacities for strengthening the innovativeness of the same companies. The implementation of these measures can help create an environment that fosters competitiveness of SMEs. Competitive SMEs, which base their business activities on knowledge and technology as strategic resources and on innovativeness as a business philosophy, provide the growth of production, export, general productivity and improve the position of a country at an international market.

Many measures are being conducted in that direction. For instance, "National Agency for Regional Development" gives direct support to the development of competitiveness of small and medium-sized enterprises and entrepreneurs by taking part in financing the costs of consultancy services (preparing a business plan, researching the market, certification and standardization, improvement of the production process, introduction of new systems of quality, implementation of innovations) in the form of grants. The Ministry of Economy and Regional Development of the Republic of Serbia in

\footnotetext{
${ }^{4}$ This practice was confirmed in the European Union and other developed countries.
} 
cooperation with National Agency for Regional Development provided grants (100,000-1,500,000 dinars) for improvement SMEs innovativeness. The general goal of this measure was to enforce investment of SMEs and entrepreneurs into innovative projects in order to increase their competitiveness, while the specific goal were increasing investments in technological and non-technological innovations, encouraging the cooperation of SMEs with institutes, laboratories and technological parks, and increasing the number of SME that could implement innovative projects. The resources from this fund can be used for: introducing new products, innovating the existing products and services and introducing a new production process (National Agency for Regional Development, 2013).

Since 2005, the RS Ministry of Economy has launched the project entitled "Project support cluster development." As a result of these activities there is the large number of clusters in Serbia, such as: Automotive Cluster, Cluster of small agricultural machinery and equipment BIP, Cluster of flowers Šumadijski cvet, Cluster of Knjaževac etc.

All of the aforementioned measures represent significant support for the development of entrepreneurship and the SME sector in Serbia. However, the problem is in the fact that those funds are limited, so that only a small number of SME and entrepreneurs can receive these funds. Therefore, the implementation of the aforementioned measures does not still have satisfactory results. This is best evidenced by the low innovativeness of SMEs in Serbia.

In Serbia, only every fourth company implements its own innovations and every eight has a long-term established cooperation with research institutions. If the relationship between the size of a company and the representation of innovations is observered, it can be concluded that innovations in small enterprises are represented with $29.10 \%$ while their part in medium-sized enterprises is $40.32 \%$. The acquired data about the innovations themselves which are represented in SME tell us that product and service innovations have $24.86 \%$ participation in the business dealings of small-sized enterprises, and $33.30 \%$ of medium-sized enterprises. Process innovations are more aggregately represented than product and services innovations, by $31.15 \%$ in small and 43.54 in medium-sized enterprises. From the total number of innovations, $36.46 \%$ of innovations are new at the market, while $63.54 \%$ of innovations are new only for the given company (National Agency for Regional Development's Report, 2011, 63).

These data lead to the fact that, unlike small and medium-sized enterprises in developed countries, small and medium-sized enterprises in Serbia have not fully accepted innovations as strategic resources. The similar conclusion can be derived on the basis of the accomplished effects of introduced innovations, which are shown in Table 1. 
Table 1. The Effects of Introduced Innovations in Small and Medium-Sized Enterprises

\begin{tabular}{||l|r|r|r|}
\hline \multicolumn{1}{|c|}{ The effects (\%) } & \multicolumn{1}{c|}{ Total } & \multicolumn{1}{c|}{$\begin{array}{c}\text { Small } \\
\text { enterprises }\end{array}$} & $\begin{array}{c}\text { Medium } \\
\text { enterprises }\end{array}$ \\
\hline $\begin{array}{l}\text { Increasing the assortment of } \\
\text { products and services }\end{array}$ & 23.64 & 21.77 & 29.69 \\
\hline $\begin{array}{l}\text { Replaced outdated products and } \\
\text { processes }\end{array}$ & 19.51 & 18.95 & 21.33 \\
\hline $\begin{array}{l}\text { Penetration to new markets and } \\
\text { increase market share }\end{array}$ & 14.99 & 13.11 & 21.09 \\
\hline $\begin{array}{l}\text { Improving the quality of products } \\
\text { and services }\end{array}$ & 28.82 & 28.17 & 30.94 \\
\hline Increased flexibility of production & 17.19 & 17.60 & 15.86 \\
\hline Increase production capacity & 18.07 & 16.32 & 23.75 \\
\hline $\begin{array}{l}\text { Reducing labor costs per unit of } \\
\text { product }\end{array}$ & 14.94 & 13.98 & 18.05 \\
\hline $\begin{array}{l}\text { Reduction of material costs per } \\
\text { unit products }\end{array}$ & 11.21 & 10.31 & 14.14 \\
\hline $\begin{array}{l}\text { Reducing the environmental } \\
\text { adverse effects }\end{array}$ & 13.61 & 12.50 & 17.19 \\
\hline
\end{tabular}

Source: Report on SMEs and Entrepreneurship for 2010, (2011)

National Agency for Regional Development, http://narr.gov.rs/index

The data from Table 1 show that innovations had the biggest impact on the improvement of the products and services in overall part of $28.82 \%$, and they had the smallest effect on the reduction of cost by the units of product with $11.21 \%$. As far as the product and services assortment is concerned, the realization of an innovation in small and medium-sized enterprises contributed in assortment increase by $23.64 \%$, and innovations that changed outdated products and processes had the $19.51 \%$. One of the most significant consequences of the realization on innovations is the entrance into new markets and increasing the involvement in a market. Innovations which in SMEs in Serbia have made it possible to enter new markets account for $13.11 \%$ in small and $21.09 \%$ in medium-sized enterprises. On the basis of the aforementioned data it can be concluded that medium-sized enterprises achieved greater commercialization of their innovations than small-sized enterprises did, but that the relative participation of these innovations is at a low level. Implemented innovations offered a more flexible production system by $17.19 \%$ and they increased production capacities of SMEs by $18.07 \%$. The influence of innovations on the input costs reduction is at a low level. Investments had a $11.21 \%$ influence on the reduction of costs per unit of production and $14.94 \%$ on the reduction of work costs per unit of production. Also, one of the significant effects of implemented innovations is the reduction of negative 
influence on environment. Eco-innovations had a participation of $17.19 \%$ in medium and $12.50 \%$ in small-sized enterprises.

Although many SMEs have accepted innovations as a means of increasing competitiveness both at the local and international market, their capability for innovations is at the beginning. In most of the cases, low degree of innovativeness is the result of the lack of financial resources and high costs of innovative processes. However, there is a large number of small and mediumsized enterprises which have not still accepted innovations as the part of their business strategies. The most common reasons for that are the lack of qualified staff and uncertain demand and the risk of inadequate market product valorization. The other restrictions include insufficient awareness about market possibilities, lack of education about innovative activities and difficulties in finding cooperation partners.

\section{Conclusion}

It can be concluded that the global economic crisis has left many problems to the economy and businesses globally. In order to solve these problems in the post-crisis period businesses have to implement a number of different measures. One of the most important set of measures is aimed at increasing the competitiveness of businesses, and hence national competitiveness, is to encourage innovation.

Innovation is the main driver of economic growth and development. The introduction of new technologies, the development of new and improved ideas, constantly improvement of the quality of products and services are some of the basic conditions for the survival of any company in the market. Small and medium-sized enterprises that have simple organizational structure and characterized by a high degree of flexibility have basic precondition to implement innovative ideas. At the same time, SMEs are the major driving force of economic development of each country and potential generators of entrepreneurial ideas and innovations. However, serious limitations of SMEs are the lack of resources, knowledge and technology needed for research and development and implementation of technological innovations that have the largest contribution to the increase of competitiveness. To solve this problem it is necessary that the state implemented a series of measures. The paper discusses how the innovative capacity of small and medium-sized enterprises can increase by implementation of financial incentives, the establishment scientific and technological parks, high tech incubators and encouraging cooperation with large enterprises.

Serbia as an underdeveloped country that seeks membership in the European Union should be more involved in the international market and increase the share of exports and imports in GDP. Export orientation of 
domestic enterprises should be based on the development of new technologies that will enable the production of innovative products and higher quality products. For these reasons it is necessary to implement a large number of incentives towards more innovative businesses, especially SME innovative companies that have a very large share of the economy.

In Serbia, certain measures to encourage innovation have been implemented, but given that the innovation of SMEs in Serbia are at a much lower level than the EU average, it can be concluded that these measures are insufficient. Therefore, policy makers may suggest much more incentives to provide innovative SMEs, since the establishment of productive research and innovation system, creating a knowledge base and technology can improve the business performance of SMEs, increase their competitiveness and thus the competitiveness of the economy as a whole.

\section{References}

Bugar, D., Tomić, G., Tomić, A. (2012) Managing innovation-a factor of comperitiveness in the global context, International Scientific Conference, „SYMORG 2012: Innovative management and business performance“, Faculty of Organizational Sciences Belgrade: $1845-1852$.

Busse, C. and C. M. Wallenburg (2011), "Innovation Management of Logistics Service Providers: Foundations, Review and Research Agenda", International Journal of Physical Distribution \& Logistics Management, 41 (2): 187-218.

Borch, O. and E. Madsen (2007) "Dynamic capabilities facilitating innovative strategies in SMEs", Technoentrepreneurship, 1 (1): 109-125

Eisenhardt, K.M. and J.K. Martin (2000) "Dynamic capabilities: What are they?" Strategic entrepreneurial challenge of constructing a resource base, Academy of Management Journal, 21 (3): 1105-1121.

European Commission (2012) "European Innovation Management Landscape", EU: European Commission, http://www.symple.tm.fr/uploaded/pdf/1-IMProve European_Innovation\%20Management_landscape.pdf (pristupljeno:31.10.2013.)

European Commission (2012) "Annual Report on small and midium - size enterprises in the EU”, European Commission, http://www.eubusiness.com/topics/sme/report -smes-11 (pristupljeno: 31.10.2013)

European Commission (2013) "COSME Programme for the competitiveness of enterprises and SMEs 2014-2020",

http://ec.europa.eu/cip/files/cosme/cosme_factsheet_final_en.pdf (pristupljeno:31.10.2013)

Galende, J. and De la Fuente J. (2003) "Internal factors determining a firmś innovative behavior", Research Policy, 32 (5): 715-736.

Ivanović-Djukić, M. (2008) „Strategy of small and medium enterprises in terms of globalization“, International Scientific Conference, „Competitiveness in the Condition of a Global Economy“", Faculty of Economics, Niš: 317-324

Kaufmann, H. R. (2009) “The Contribution of Entrepreneurship to Society", International Journal of Entrepreneurship and Small Business, 7 (1): 59-72. 
Kaufmann H., H. Tsangar and D. Vrontis (2012) "Innovativeness of European SMEs: Mission not yet accomplished", Economic research, 25 (2): 333-360.

Khazanchi, S., Lewis, M.W. and Boyer, K.K., (2007), "Innovation-Supportive Culture: The Impact of Organizational Values on Process Innovation", International Journal of Physical Distribution \& Logistics Management, 41 (2): 187-218.

Lazić, M. (2013), "Upravljanje intelektualnom svojinom u funkciju unapređenja uspešnosti poslovanja preduzeća" (master rad), Niš: Ekonomski fakultet.

Martín-de Castro, G., M. Delgado-Verde, J.E. Navas-López and J. Cruz-González (2013), "The moderating role of innovation culture in the relationship between knowledge assets and product innovation" Technological Forecasting and Social Change, 80(2):351

McAdam, R., S. Moffett, S.A. Hazlett and M. Shevlin (2010), "Developing a Model of Innovation Implementation for UK SMEs: A Path Analysis and Explanatory Case Analysis", International Small Business Journal, 28 (3): 195-214.

Milisavljević, M. (1993), Inovacije i tehnološka strategija preduzeća, Beograd: Ekonomski fakultet Beograd.

Ministarstvo ekonomije i regionalnog razvoja (2011) "Izveštaj o malim i srednjim preduzećima i preduzetništvu za 2010. godinu", Beograd: Ministarstvo ekonomije i regionalnog razvoja, www.policycafe.rs/financial-research.php (pristupljeno: 31.10.2013)

Molina-Morales, F.X., P. M. Garcia-Villaverde and G. Parra-Requena (2011), "Geographical and cognitive proximity effects on innovation performance in SMEs: a way through knowledge acquisition", International Entrepreneurship and Management Journal, 13 (1):1-21.

Nacionalna agencija za regionalni razvoj (2011), “Izveštaj o malim i srednjim preduzečima i preduzetništvu za 2010. godinu", Beograd: Nacionalna agencija za regionalni razvoj http://narr.gov.rs/index.php/Info/Konkursi/Javni-poziv-za-jachanje-inovativnosti-u2011 (pristupljeno, 2.7.2013.).

Porter, M.(2008) „Clusters and The New Economy of Competition“ Harvard Business Review, 3:77-90.

Romero, I. and J. A. Martine-Roman (2012), "Self-employment and innovation. Exploring the determinants of innovative behaviour in small business". Research Policy, 41(1), 178-189.

Schumpeter, J. (1947), "The creative Respose in Economic History" The Journal of Economic History, 7 (2): 149-159.

Stefanovic, S. and Ivanovic-Djukic M. (2011), Support to the Development of Entrepreneurship in the Nišava Region in order to Increase Competitiveness and Overcome Economic Crisis, Thematic collection of papers: Experiences in Overcoming the Global Economic Crisis - The Cases of Italy and Serbia, Faculty of Economics Nis, University Ca'Foscari-Venice: 187-208.

Thompson J., Strickland A., (2001), "Crafting and Executing Strategy: Text and Readings", Irwin McGraw-Hill, New York.

Urbancová H. (2013) "Competitive Advantage Achievement through Innovation and Knowledge", Journal of competitveness, 5 (1): 82-96.

World Economic Forum (2012) "The Global Competitiveness Index Raport 2012-2013", World Economic Forum, "http://www3.weforum. org/docs /WEF_GCR_ CompetitivenessIndex Ranking_2012-12.pdf (pristupljeno, 15.03.2013 


\title{
PODSTICANJE INOVATIVNOSTI MALIH I SREDNJIH PREDUZEĆA U SRBIJI U FUNKCIJI UNAPREĐENJA KONKURENTNOSTI U POSTKRIZNOM PERIODU
}

\begin{abstract}
Apstrakt: Globalna ekonomska kriza je ostavila veliki broj posledica. Da bi se one prevazišle, potrebno je u postkriznom periodu sprovesti različite mere na makroekonomskom i mikroekonomskom nivou. Veliki broj razvijenih zemalja i zemalja $\mathrm{u}$ razvoju je kao ključne poluge $\mathrm{u}$ postkriznom periodu prepoznao sektor malih i srednjih preduzeća (MSP), tako da je najveći broj mera makroekonomske politike usmeren na podsticanje njegove konkurentnosti. U prošlosti mala i srednja preduzeća su konkurentsku prednost uglavnom gradila fokusiranjem na specifične tržištne niše, fragmentirane grane ili vođstvom u troškovima, dok u savremenim uslovima poslovanja sve značajniji izvor njihove konkurentnosti postaje sposobnost inoviranja. Međutim, pošto su kapaciteti malih i srednjih preduzeća za uvođenje tehnoloških inovacija uglavnom ograničeni, potrebna je jaka makroekonomska podrška za povećanje inovativnosti MSP. U ovom radu će upravo biti objašnjene mere kojima se može uticati na povećanje inovativnosti MSP. Takođe će biti analiziran uticaj inovativnosti MSP na njihovu konkurentnost i konkurentnost privrede u kojoj posluju. Poseban osvrt biće na analizi inovativnosti MSP u Srbiji.
\end{abstract}

Ključne reči: inovacije, konkurentnost, mala i srednja preduzeća, globalna ekonomska kriza. 